\title{
REVIEW ON DESIGN STRATEGIES OF ENERGY SAVING OFFICE BUILDING WITH EVAPORATIVE COOLING IN TROPICAL REGION
}

\author{
Rizvanda Ryan Savero I I Gusti Ngurah Antaryama* | Bambang Soemardiono
}

Department of Architecture, Institut Teknologi Sepuluh Nopember, Surabaya, Indonesia

\section{Correspondence \\ *I Gusti Ngurah Antaryama, Department of Architecture, Institut Teknologi Sepuluh Nopember, Surabaya, Indonesia. Email: antaryama@arch.its.ac.id}

\section{Present Address}

Gedung Arsitektur, Kampus ITS Sukolilo, Jl. Raya ITS, Surabaya 60111, Indonesia

\begin{abstract}
This research reviews the theories and design of energy-saving office buildings that apply evaporative cooling concepts to inhibit solar heat and improve natural cooling. The limited land in urban areas forces the building orientation facing East-West to increase building heat gain in tropical regions. This research is interesting because evaporative cooling is rarely found in office building design, especially in tropical areas. The method used is literature searching (theory, journal, and president) related to the energy-saving building (passive design) and passive cooling with evaporative cooling techniques. A review of design strategies can be used as a reference for general criteria applied at the design stage of office building architectural design. As a limitation, questions are needed to find related theories such as (1) what are the factors of building heat control and the criteria required in designing energy-saving office building (2) how to apply evaporative cooling techniques to design the energysaving office building. Solar heat is a key factor in building heat gain. So it must be noticed to control building heat to protect heat transfer into buildings. The results of the design energy saving office buildings in the tropical region have required the application of passive designs such as building orientation, building core placement, shading elements, cross ventilation, natural lighting, producing shape, and application of evaporative cooling with consideration of wind direction and hottest side due to solar radiation.
\end{abstract}

\section{KEYWORDS:}

Energy Saving, Evaporative Cooling, Literature Review, Office Building, Passive Design 


\section{1 | INTRODUCTION}

Energy consumption in office buildings reaches $41 \%$, among other facilities. This is generally due to the vastness of office buildings so that the energy needed is also getting more significant. The most considerable electricity consumption is used as lighting (39\%), then as air conditioning (14\%), and ventilation (9\%) [1]. Using glass material suggests that architectural design feels more modern, hi-tech, and luxurious in the office building. But as we know, the glass material can increase the building's temperature or the urban environment (heat island effect) ${ }^{[2]}$.

In hot climate areas, functions that require high energy consumption for cooling shall be placed on a higher level to get the advantage of low air temperature and reduce the cooling load. This in case those levels are located above the urban canopy. In the districts that include a high number of tall buildings, whereby the entire building lies under the urban canopy, the heat loss rate decreases with the increase in height. Thus, the function with a high occupancy rate should be placed on the building's lower level ${ }^{[3}$. Nowadays, the limited land in the urban area forces the building orientation facing East-West that increases building heat gain in the tropical region.

Building design should maximize passive mode and minimize full-mode. This can be achieved with the orientation of the shape of the building, the arrangement of layouts on land, facade design, solar-control devices, passive daylight devices, building envelope materials, vertical landscape, and passive cooling (passive cooling system) ${ }^{[4}$.

This research discussed how good strategies in applying passive designs are important in tropical climates from some of these theories. In addition, building form references that are energy efficient also need to be considered. Optimizing energy savings can also be applied with passive cooling. One passive cooling technique suitable for the tropical climate is evaporative cooling. The application of evaporative cooling is ideal for dry and humid climate conditions ${ }^{[2]}$.

\section{2 | MATERIAL AND METHOD}

The method used is literature searching from books, journals, precedents, and other relevant sources. The literature includes the following: (1) the theory of building passive design; (2) the theory of passive cooling related to the evaporative cooling technique; (3) the theory of shape and geometry of energy-saving buildings; (4) the precedent about energy-saving office building; (5) the evaporative concept; and (6) the shape and geometric for the energy-saving office building.

From the literature searching, the contents of the theories that are most often appear and are used as energy-saving strategies in office buildings are analyzed. Then it would be clarified by the precedent that applies the theory. The relationship between theory and precedent would validate the accuracy of the office building energy-saving strategy in the tropical climate. Table 1 shows the comparison between three office building theories in term of energy efficiency.

\section{3 | RESULTS AND DISCUSSION}

\section{1 | Passive Design}

In designing energy-saving office buildings, solar radiation is a priority to reduce building cooling energy consumption. Solar radiation has a large effect on increasing room temperature of office buildings, so that the control of building heat is important.

From theories, books, journals, and references, we can compare all aspects of passive design that important to be implemented in an office building in a tropical region (Table 1).

Many aspects influence the creation of energy-efficient office buildings. Most lead to the passive design of buildings. Buildings should maximize passive mode and minimize active mode ${ }^{[5}$. From the literature discussed above, the most frequently occurring aspects will be clarified with detailed descriptions. These aspects include building orientation, core placement, sun shading, cross ventilation, and natural lighting. Shape, form and geometry mentioned by Elotefy et al., 2015, should be considered because it has a different perspective but rational idea. 
TABLE 1 Comparison of energy consumption efficiency between office buildings theories.

\begin{tabular}{|c|c|c|c|c|}
\hline & & OAS (2013) & Elotefy (2015) & Sayigh (2017) 1 \\
\hline $\begin{array}{l}\text { Core Placement } \\
\text { Cores should prefer- } \\
\text { ably be located on the } \\
\text { hot east and west sides } \\
\text { of the building. With } \\
\text { both cores on the hot } \\
\text { sides, they provide } \\
\text { buffer zones, internal } \\
\text { insulating spaces. } \\
\text { Building Adjustment } \\
\text { Arranging the building } \\
\text { with its immediate and } \\
\text { broader openings facing } \\
\text { north and south gives } \\
\text { advantages in reducing } \\
\text { insulation. } \\
\text { Transitional Spaces } \\
\text { Transitional spaces } \\
\text { might be introduced in } \\
\text { the central and periph- } \\
\text { eral parts of building as } \\
\text { air spaces and atrium } \\
\text { Solar Shading } \\
\text { Configuration of pas- } \\
\text { sive devices can be } \\
\text { used (fins, spandrels, } \\
\text { egg-crates, etc.). Shad- } \\
\text { ing blocks insulation in } \\
\text { summer and prevents } \\
\text { heat penetration of the } \\
\text { building. }\end{array}$ & $\begin{array}{l}\text { Cross Ventilation } \\
\text { Good air movement } \\
\text { promotes heat emission } \\
\text { of the human body sur- } \\
\text { face and gives a feeling } \\
\text { of comfort. } \\
\text { Water Spray Wall } \\
\text { A water-spray system } \\
\text { on hot facades promotes } \\
\text { evaporation and there- } \\
\text { fore cooling. } \\
\text { Cross Ventilation } \\
\text { In each side of the } \\
\text { room, at least two ven- } \\
\text { tilated sides are needed. } \\
\text { Cross ventilation can } \\
\text { remove hot air and be } \\
\text { replaced by fresh air. } \\
\text { Another option is using } \\
\text { convective ventilation, } \\
\text { hot air flows upward } \\
\text { and is replaced by fresh } \\
\text { air. } \\
\text { Sun Protection } \\
\text { Sun protection aims to } \\
\text { reduce solar heat and } \\
\text { prevent direct light into } \\
\text { the building } \\
\text { Natural Lighting } \\
\text { The light deflecting sys- } \\
\text { tem allows lighting with } \\
\text { the daytime condition to } \\
\text { maintain certain light- } \\
\text { ing levels. } \\
\text { Building Site and Ori- } \\
\text { entation } \\
\text { The orientation of } \\
\text { the building should } \\
\text { consider both the } \\
\text { protection from the sun. }\end{array}$ & $\begin{array}{l}\text { Cross Ventilation } \\
\text { The opening at the } \\
\text { façade at higher wind } \\
\text { pressure to another } \\
\text { opening at a lower } \\
\text { pressure. } \\
\text { Solar Shading } \\
\text { Design elements that } \\
\text { create shade during the } \\
\text { months of highest tem- } \\
\text { peratures, determining } \\
\text { solar incidence angles } \\
\text { for the site (latitude). } \\
\text { Transition Spaces } \\
\text { Spaces between the } \\
\text { inside and outside } \\
\text { protect the walls and } \\
\text { the inner space from } \\
\text { climatic conditions, } \\
\text { generating a shaded } \\
\text { area with an air- } \\
\text { flow and, therefore, a } \\
\text { cooling effect. } \\
\text { Vegetation } \\
\text { Vegetation is possible } \\
\text { and beneficial in the } \\
\text { courtyards, to decrease } \\
\text { the heat gain. } \\
\text { Daylight } \\
\text { This reduces the elec- } \\
\text { tricity demand for artifi- } \\
\text { cial lighting. }\end{array}$ & $\begin{array}{l}\text { Vertical Design } \\
\text { In hot climate areas, } \\
\text { functions that require } \\
\text { high energy consump- } \\
\text { tion for cooling shall be } \\
\text { placed on a higher level } \\
\text { to get the advantage of } \\
\text { low air temperature and } \\
\text { reduce the cooling load. } \\
\text { Core Location } \\
\text { The building core } \\
\text { should be placed on } \\
\text { the façade with the } \\
\text { high solar radiations } \\
\text { exposure in a hot } \\
\text { climate } \\
\text { Shape, form and } \\
\text { geometry } \\
\text { In a hot climate, the } \\
\text { contrast between the } \\
\text { building shape and the } \\
\text { surface pattern reduce } \\
\text { the energy consump- } \\
\text { tion in buildings that } \\
\text { have a fixed extruded } \\
\text { shape from the building } \\
\text { plan as it helps in con- } \\
\text { trolling wind directions } \\
\text { and decrease the effect } \\
\text { of solar radiation on } \\
\text { the building's facades } \\
\text { via providing more } \\
\text { shading. } \\
\text { Natural Ventilation } \\
\text { The use of external } \\
\text { opening along with the } \\
\text { courtyards improves } \\
\text { the natural ventilation } \\
\text { via the stack effect. } \\
\text { Building Orientation } \\
\text { The optimum aspect } \\
\text { ratio of the built form } \\
\text { should be as } 1: 2-1: 3 \text { for } \\
\text { climatic zones nearer to } \\
\text { the equatorial zone. }\end{array}$ & $\begin{array}{l}\text { Core Placement } \\
\text { In arid and tropical } \\
\text { regions, the service } \\
\text { cores of the building } \\
\text { should be located on } \\
\text { the east and west sides } \\
\text { of the building. } \\
\text { Floor-Plate Shape } \\
\text { The optimum shape is } \\
\text { a rectangle that min- } \\
\text { imizes the length of } \\
\text { the east and west sides } \\
\text { while maximizes that of } \\
\text { north and south sides. } \\
\text { Building Skin } \\
\text { Its permeability to } \\
\text { light, heat, and air and } \\
\text { its visual transparency } \\
\text { must be controlled with } \\
\text { modification flexibility. } \\
\text { Shading Device } \\
\text { Solar shading is needed } \\
\text { on the east, west, and } \\
\text { south sides of the build- } \\
\text { ing, especially during } \\
\text { the overheated period. } \\
\text { Glazing } \\
\text { Low-e glass reduces } \\
\text { direct heat gain by } \\
\text { transmitting a greater } \\
\text { the proportion of light } \\
\text { than heat. } \\
\text { Natural Light } \\
\text { Optimizing the use of } \\
\text { daylighting and } \\
\text { minimizing the need } \\
\text { for artificial lighting }\end{array}$ \\
\hline
\end{tabular}

\section{2 | Building Orientation}

The building's arrangement with the opening facing north and south provides an advantage in reducing heat insulation. The best building orientation is the smallest surface area facing east-west, providing an external wall outside the room. Window openings should be north and south-facing. It is very important to get a view orientation. For aesthetic reason, a curtain wall can be used on building facades that do not face the sun ${ }^{4}$.

The building shape should extend from east to west so that the building's long side faces north and south. The optimum aspect ratio of the building shape for the climate in the equatorial zone (tropical) is 1:2;1:3 [1]. Figure 1 shows the building orientation on tropical climate.

\section{3 | Core Placement}

Building core placement is located on the east or west side of the building to shadow when the sun is at a low angle. The research shows that in a dual-core configuration, with ventilation on the north-south side and building core on the east-west side, it can save on air conditioner usage ${ }^{[1]}$. Figure 2 shows the proposed building core placement. The building core's location should be 
placed on the façade with the high solar radiation exposure in hot climate ${ }^{11}$. Figure 3 shows the service core location according to Elotefy (2015) [3]

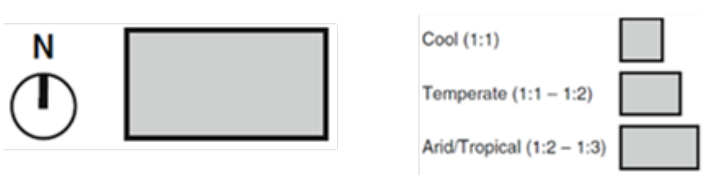

FIGURE 1 Building orientation on tropical climate is $1: 2,1: 3$.

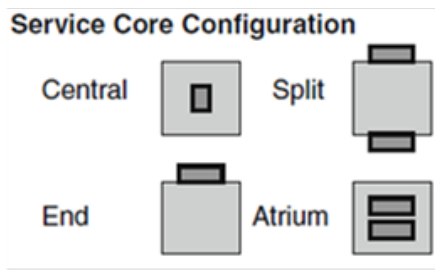

FIGURE 2 Building core placement.
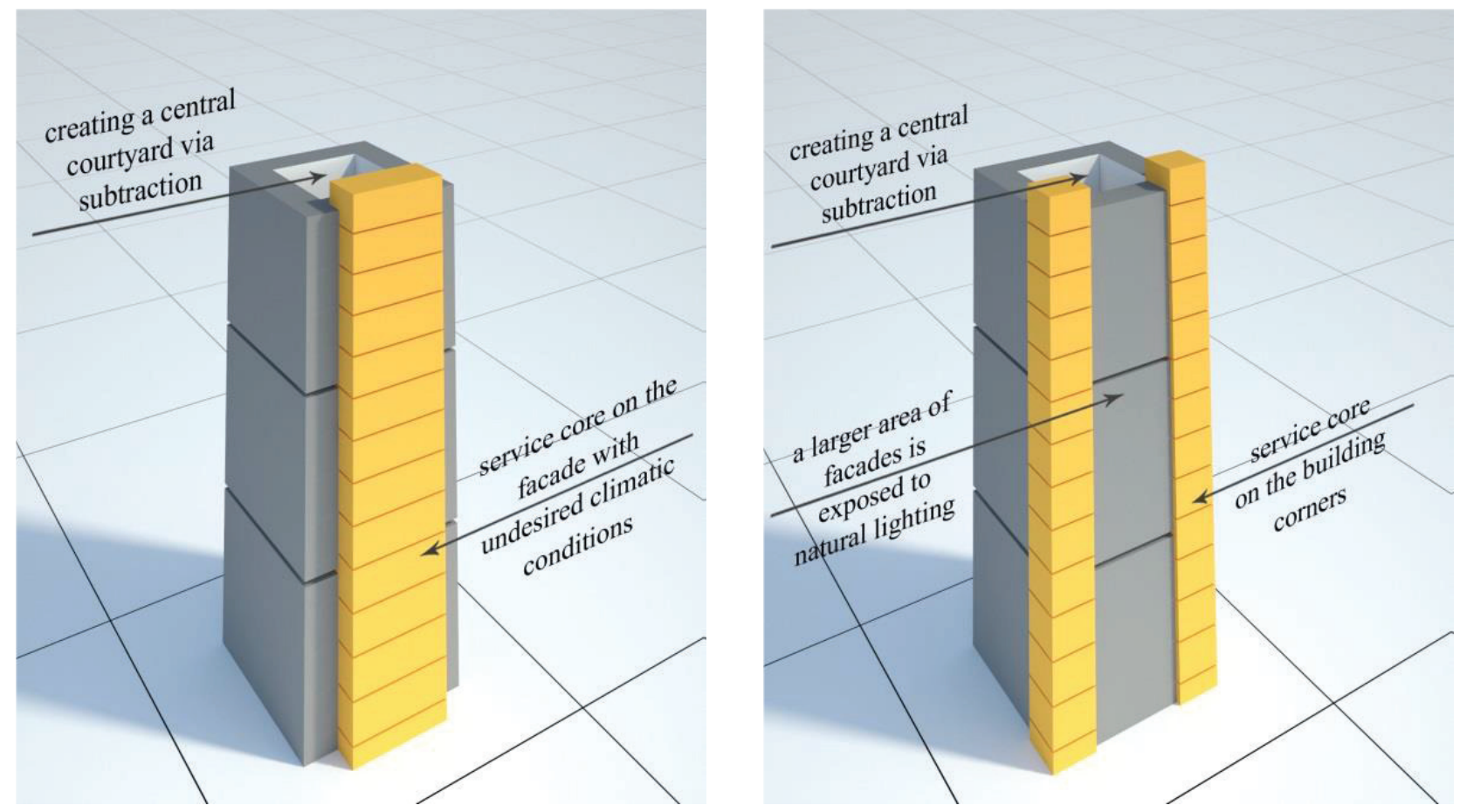

FIGURE 3 Service core location.

\section{4 | Sun Shading}

In tropical climates, building facades must be movable to control ventilation for thermal comfort in buildings. Passive shading can be placed on the side facing the sun (East-West) ${ }^{[4]}$. Figure 4 shows the proposed passive shading placement.

According to Sayigh (2017) ${ }^{1}$, sun shading is needed on the east, west, south of the building. Because it has a long radiation exposure period, Lightshelves can reduce glare and support sunlight entering deeper room buildings. Fixed shading devices are more effective and no cost for operable. Portable shading devices are more expensive but flexible in control related to outside conditions. While the intelligence façade is a sunshade that operates automatically following solar radiation or outdoor temperature.

According to Gonzalo (2006) ${ }^{6}$, sun shading aims to reduce solar heat radiation and block the direct light into the building. Figure 5 shows the proposed shading device. Sun shading depends on the window on the building. Sun shading system can be 
adjusted (automatic or manual) to control heat gain and light radiation. A fixed shading device requires proper calculation and accurate design, so that heat and light radiation is as expected.
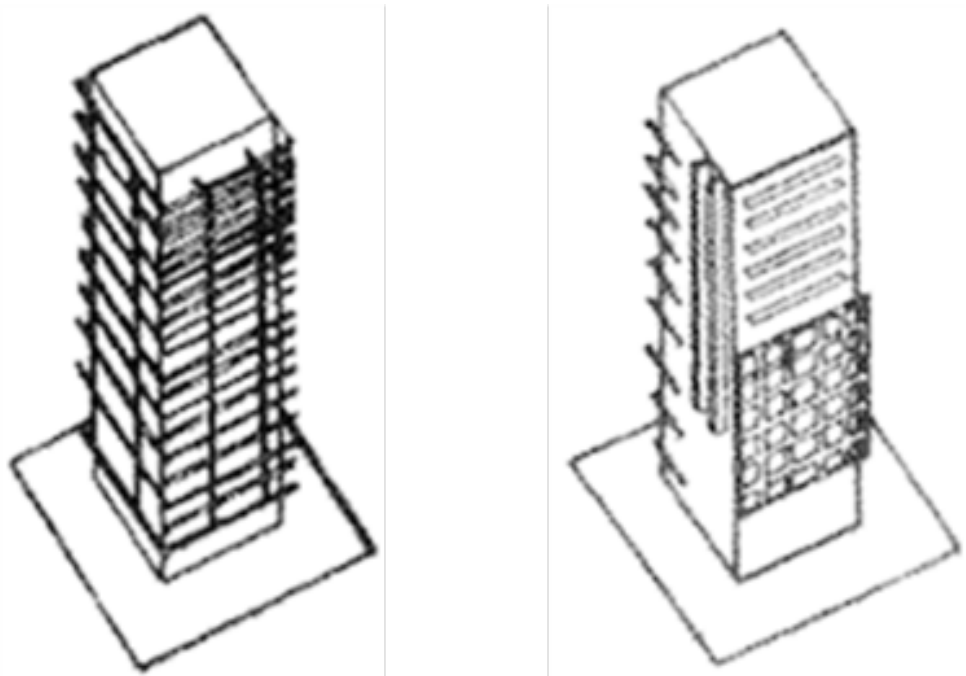

FIGURE 4 Passive shading can be placed on the side facing the sun (East-West).

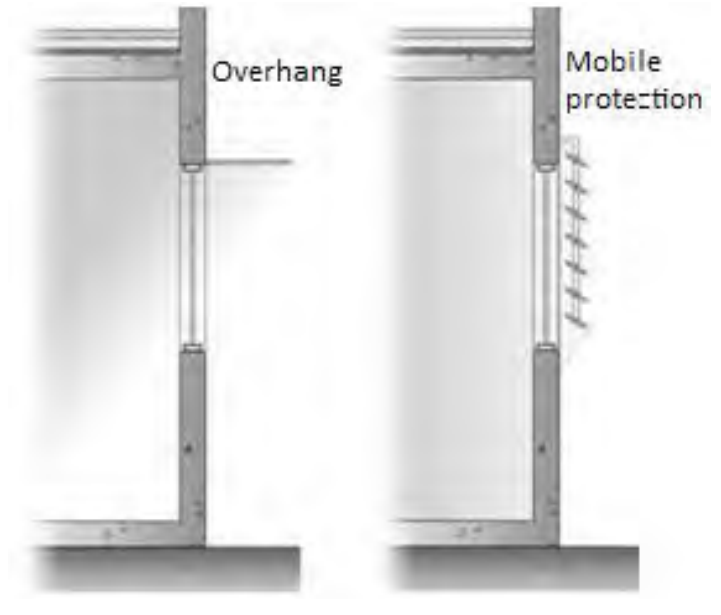

FIGURE 5 Shading device may be fixed or flexible.

\section{5 | Cross Ventilation}

Cross ventilation is used to provide fresh air into the building. It is maximizing heat release from buildings, opening windows, jalousies that allow cross air circulation. Airflow can helps thermal comfort ${ }^{14}$. Figure 6 shows the proposed cross ventilation.
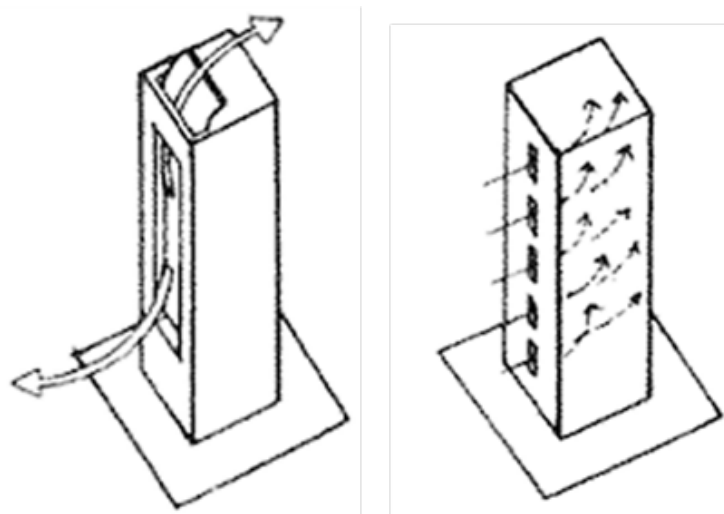

FIGURE 6 Cross ventilation in high rise building.

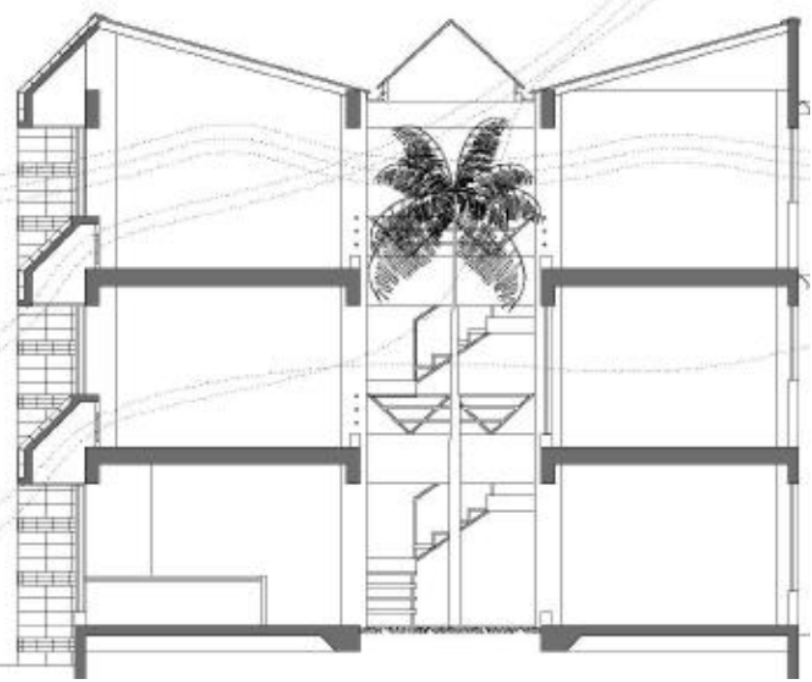

FIGURE 7 Buildings with opposed facades and connected spaces may have air flows that provide improved thermal Comfort 
According to Gonzalo (2006) ${ }^{6}$, at least two sides have ventilation in each zone of the room. This aims to cross-ventilation, which can remove hot air and be replaced by fresh air. Another option is using convective ventilation (stack effect), where hot air will flow upwards and be replaced by fresh air. Figure 7 shows the building with opposed facades and connected spaces ${ }^{7}$.

\section{6 | Natural Lighting}

Optimizing natural light can reduce the energy consumption of artificial light and reduce heat gain from artificial light. Natural light is a key factor in interior design and supports visual comfort for users ${ }^{8}$. Figure 8 shows the principle of reflecting sunlight with light shelves. Artificial light is a complement from natural light. Light deflecting systems allow artificial light with daylight conditions (natural light) to maintain a particular lighting level [6].

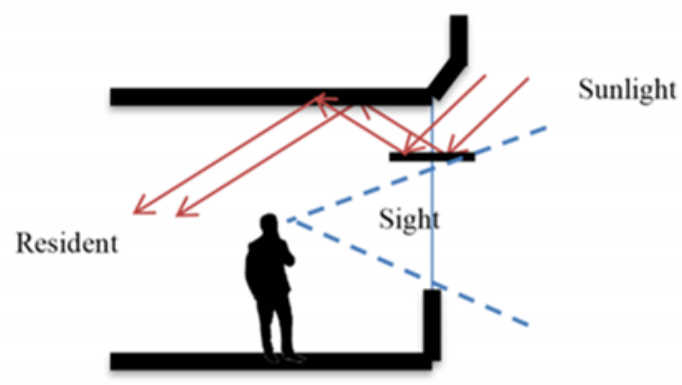

FIGURE 8 The principle of reflecting sunlight with light shelves.

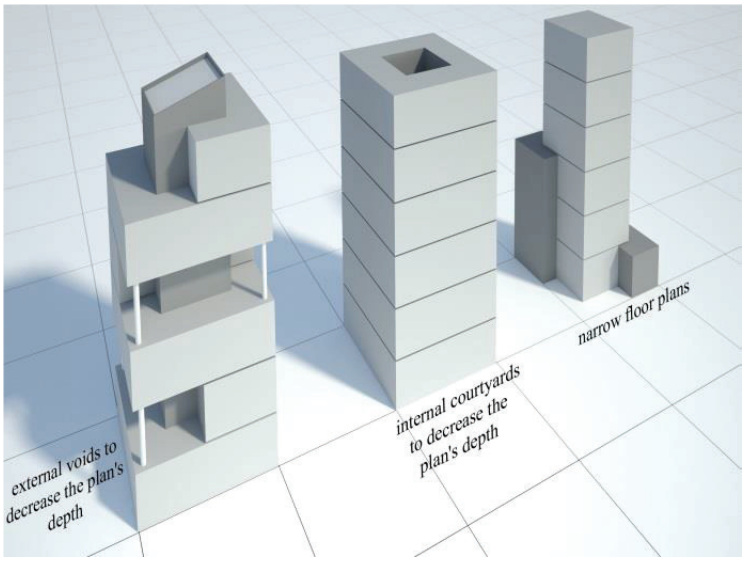

FIGURE 9 Increase the external surface area to volume ratio.

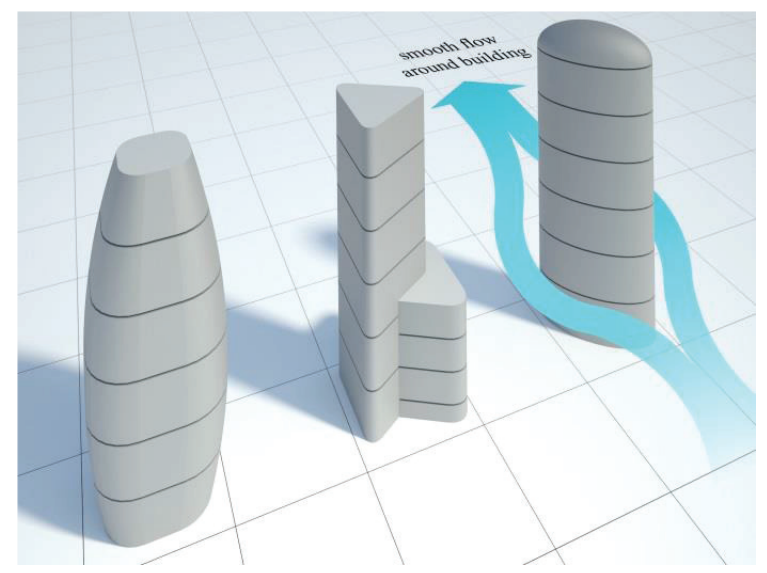

FIGURE 10 Aerodynamic shapes for tall buildings.

\subsection{Shape, Form and Geometry}

Different building geometry has affected their solar exposure as some shapes receive more solar radiation than others resulting in higher cooling loads inside the building. In addition, some shapes improve the natural daylight and ventilation flow inside the building that will decrease the thermal and ventilation load inside the building 3 .

The level of compactness, the ratio between the building surface areas to the volume, significantly impacts energy consumption. The larger the level of compactness, the more energy-efficient the can be achieved. This will decrease the depth of the internal spaces and increase natural ventilation and daylight. This can be reached via narrow plans and/or courtyards external or internal to reduce the floor depth (Figure 9) ${ }^{3}$. 
The use of aerodynamic shapes reduces the wind turbulences and waves around the buildings, leading to a decrease in the embodied energy for the building structure and the envelope's material. It also creates pressure around the building that improves the natural ventilation in the buildings. It also increases the efficiency of wind energy systems (Figure 10) ${ }^{3}$.

In a hot climate, the contrast between the building shape and the surface pattern reduce the energy consumption in buildings that have a fixed extruded shape from the building plan as it helps in controlling wind directions and decrease the effect of solar radiation on the building's facades via providing more shading (Figure 11) ${ }^{3}$.

Another technique is subtracting parts from the building on the facades exposed to solar radiation in hot climates to create voids. These voids are designed to allow the natural daylight to enter the internal spaces, increasing shading rations, and decrease the solar gain and glare on those facades (Figure 12) [3]

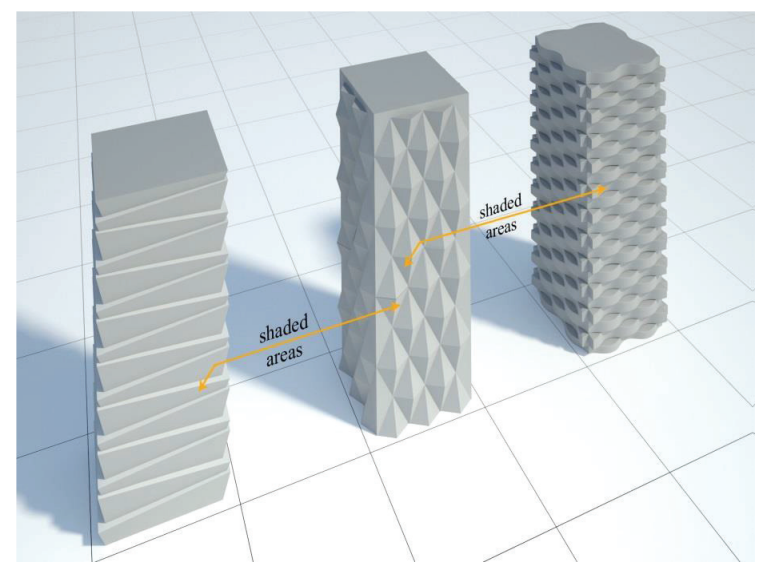

FIGURE 11 Contrast in façades surface pattern.

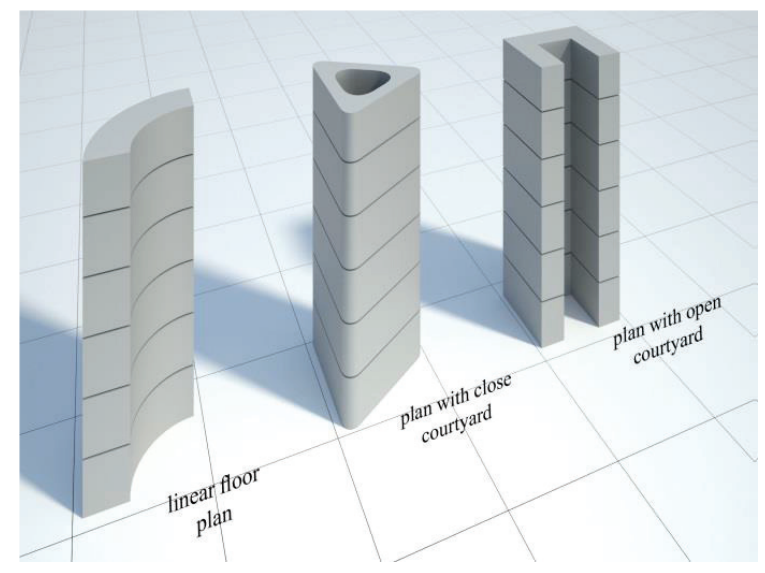

FIGURE 12 Building floor plans that support natural ventilation.

TABLE 2 Researchers related to evaporation cooling.

\begin{tabular}{l}
\hline Chungloo (2007) 9 \\
Research Experiment \\
The spraying of water \\
on the roof and the com- \\
bination of solar chim- \\
ney with the spraying \\
water on roof is recom- \\
mended during the high \\
temperature of ambient \\
water. \\
Water spraying on \\
the roof together with \\
the solar chimney can \\
reduce indoor tem- \\
peratures by $2.0-6.2$ \\
${ }^{\circ} \mathrm{C}$
\end{tabular}

Ripple (2014) 10
Research Experiment
Facades would cause
shadowing and simul-
taneous evaporation
which causes the tem-
perature around the
surface to decrease
(absorbed by air
flowing with water).
flowing with water).

$\begin{array}{ll}\text { Khadra (2014) } 11 & \text { Mainini (2016) 12 } \\ \text { Research Design } & \text { Research Experiment } \\ \text { Previous investigations } & \text { The effectiveness in } \\ \text { showed that shading, } & \text { reducing solar gains } \\ \text { natural ventilation and } & \text { strongly depends on } \\ \text { evaporative cooling are } & \text { the amoun of water } \\ \text { the most effective pas- } & \text { sprayed in the air } \\ \text { sive cooling strategies } & \text { chamber. } \\ \text { for hot and arid regions } & \text { The proposed sys- } \\ \text { The proposed façade } & \text { tems could only have } \\ \text { showed efficiency in a moderated effect in } \\ \text { performance using }\end{array}$
visual comfort.

\begin{abstract}
Al Touma (2018) 13
Research (simulation)

The simple application of the evaporativelycooled window on a typical office space subjected to such driving weather conditions was found to save $8.8 \%$ of the space total annual energy demand. During the summer, the performance of the system was enhanced by saving $11.3 \%$ of the space total daily heat gain. Should the evaporatively- cooled window be applied in hot and dry conditions throughout the year, much larger energy savings would be found during both summer and winter conditions.
\end{abstract}


All aspects include building orientation, core placement, sun shading, cross ventilation, natural lighting and building shape is important to consider designing energy-saving office building.

\section{8 | Evaporative Cooling}

Passive cooling is a strategy to reduce the temperature of the building. Some of the techniques used are designing wind into buildings, using double-skin facades, radiant cooling, evaporative cooling, cool towers, earth cooling, and solar chimney ${ }^{[2]}$. Table 2 shows the previous research related to evaporation cooling techniques.

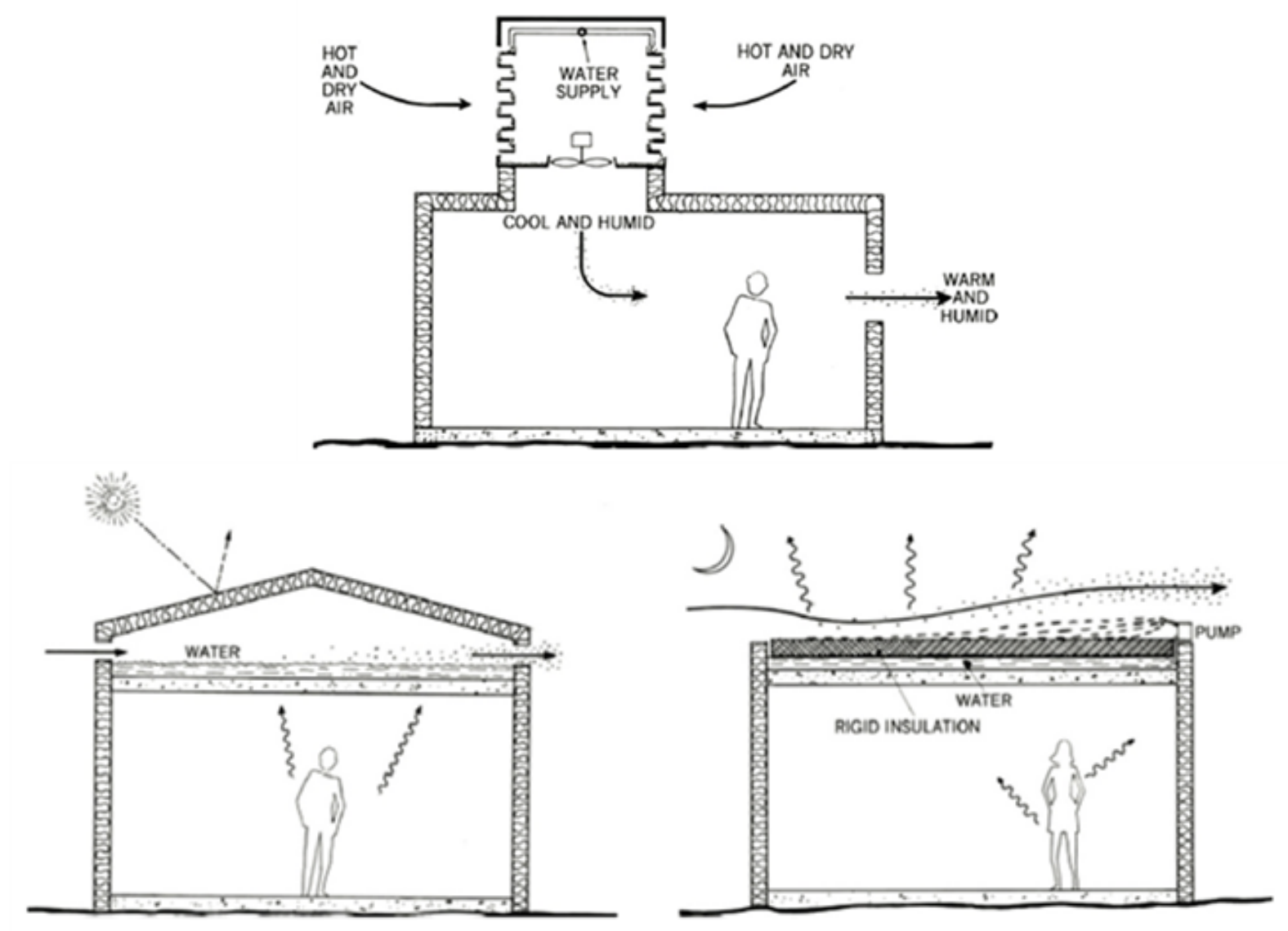

FIGURE 13 Direct Evaporation Cooling (above), Indirect Evaporation Cooling (bottom).

A building envelope is a building element that first receives solar radiation heat. Figure 13 shows the two evaporation cooling mechanisms. So that the completion of the building envelope design needs to be considered. There are several ways that building envelopes reduce solar radiation into the building. One of them is using evaporative cooling. There are two types of evaporative cooling, i.e. Direct Evaporation Cooling and Indirect Evaporation Cooling mechanism. In direct evaporation cooling system, the cooling is directed into the room of the building. While in indirect evaporation cooling, the cooling is directed to building elements that exposed the sun's heat.

According to Lechner (2015) ${ }^{[2]}$ there are three requirements with respect to evaporative cooling. They are direct evaporation, inidrect evaporation, and their combination. Direct evaporation cooling is suitable in dry tropical climates. While the indirect evaporation is very good in dry tropical climates, but it could also be used in humid tropical climates. The last one is the combination of direct and indirect evaporation cooling system. This combination would be the best choice.

In experimental research, water flow between membranes ETFE (Ethylene Tetrafluoroethylene) can reduce surface temperature to $10^{\circ}$ Celcius ${ }^{12]}$. In this research, the research's supporting components included nozzle, water hose, membrane ETFE, the 
space between ETFE membranes, thermocouples, meter fluxes, and thermal cameras. The type of nozzle and the duration of water flow significantly influence the temperature decrease in the membrane chamber (Figure 14).
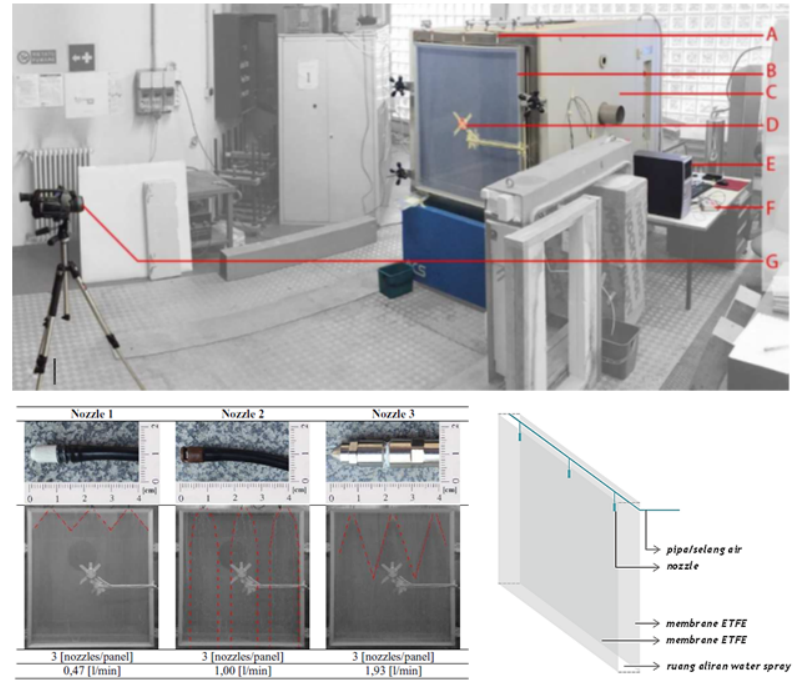

FIGURE 14 Experimental research on membrane ETFE space which is water sprayed.

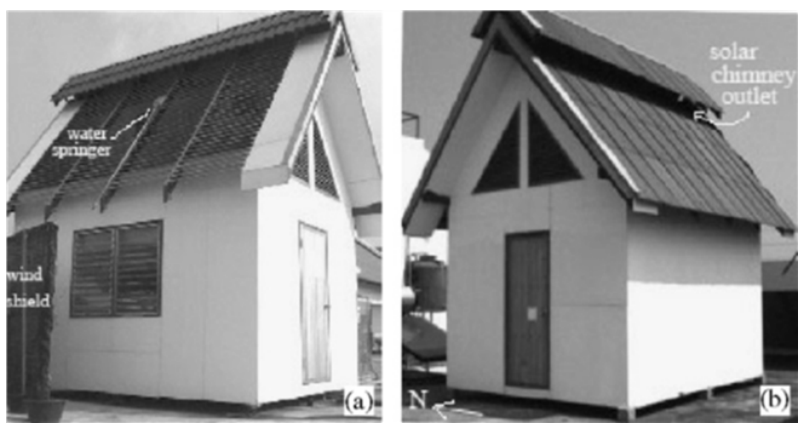

FIGURE 15 Experimental research on water flowed on the roof (Chungloo, 2007).

Other experimental research is water flowed on the roof and combined with solar chimney can reduce the room temperature between $2,0^{\circ}-6,4^{\circ}$ Celcius $[9$. In this research, the components include water tanks, pumps, water pipes, and galvanized roofs. The galvanized pipe roof is drained from the water tank by the pump in the hottest period. Water falling from the roof is accommodated, flowed into the water tank, and pumped back on the roof. This study's architectural element is on the roof elements of the building, where the roof element is the outermost element of a building. Figure 15 shows the experimental research on water flowed on the roof.

The design prototype "evaporative skin project" was carried out by Ripple Studio [10]. Utilizing aluminum performance and creating an evaporative cooling facade system passively conditions air intakes in hot and dry climates. Aluminum is more durable, mildew resistant, and gets solar heat, increasing airflow through the screen and evaporation on its surface (Figure 16).

The facades would cause shadowing and simultaneous evaporation, which causes the temperature around the surface to decrease (absorbed by air flowing with water). Facade formation such as cellulose cooling pad on the air conditioner.

The design proposes a double skin south-facing façade that is fully shaded and incorporates automated openings on the external and internal skins to induce natural ventilation (Figure 17). The outer coat is equipped with wetted pads to be used as evaporative cooling mediums. These pads are expected to cool the air before entering the cavity space and flowing into the office space.

The air temperature was reduced from $95^{\circ} \mathrm{F}$ to $70^{\circ} \mathrm{F}$ by evaporation. This mode showed compliance with thermal comfort standards for office spaces. The proposed façade showed efficiency in performance using passive cooling strategies for office spaces in hot arid regions by reducing energy consumption while promoting thermal and visual comfort 13 . This research can highly contribute to reducing energy consumption for commercial buildings and providing a healthier work environment by using renewable sources of energy $[11$.

From this research and design prototype, it is possible if a similar concept is applied to the building envelope on a larger scale, especially office building. The flow of water flowing on the surface serves to change the environment's temperature around the surface, effectively reducing the temperature of heat that would flow into the building. 


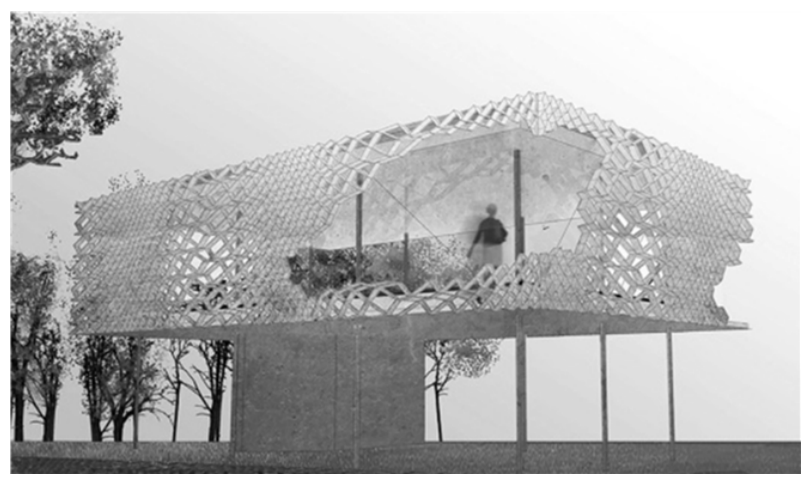

FIGURE 16 The concept of evaporative skin applied to building envelope elements (Ripple, 2014).

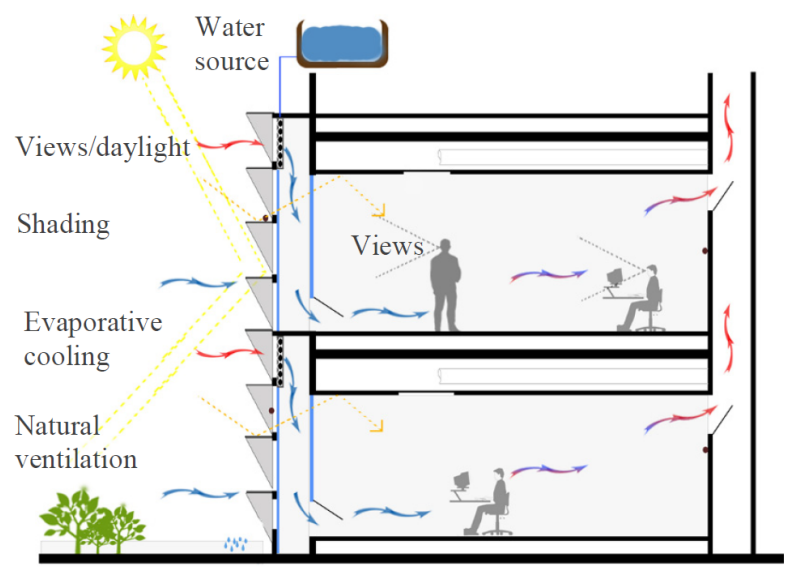

FIGURE 17 Skin which integrates passive cooling strategies while optimizing the occupants' thermal and visual comfort (Khadra, 2014).

TABLE 3 Precedent with passive design and evaporative cooling.

\begin{tabular}{|c|c|c|}
\hline Mesiniaga Tower (Malaysia) & NBF Osaki (Japan) & Council House 2 (Australia) \\
\hline $\begin{array}{l}\text { Passive Design } \\
\text { - The core is placed in the East position } \\
\text { as a heat-retaining morning sun } \\
\text { - Aluminum louvre as a barrier to solar } \\
\text { heat on the north and south side } \\
\text { - Aluminum fields cover all windows } \\
\text { on the west side to resist the heat of the } \\
\text { afternoon sun } \\
\text { - Sky courts / vegetation as interior } \\
\text { shading } \\
\text { - Passive shading device } \\
\text { - Using natural light } \\
\text { Evaporative Cooling } \\
\text { Use of an evaporative-cooling pool at } \\
\text { the uppermost level. }\end{array}$ & $\begin{array}{l}\text { Passive Design } \\
\text { - Application of building ratios } 1: 2-1 \text { : } \\
3 \text { - Using balcony as transition space and } \\
\text { providing more shadow } \\
\text { - The concept of blinds as a shading } \\
\text { element } \\
\text { - Curtains are positioned on the east- } \\
\text { west side as a barrier to solar radiation } \\
\text { - Passive shading device } \\
\text { - Using natural light } \\
\text { Evaporative Cooling } \\
\text { Using a porous pipe flowed by water and } \\
\text { applied into one part with the shading } \\
\text { element }\end{array}$ & $\begin{array}{l}\text { Passive Design } \\
\text { - Building orientation that adjusts to the } \\
\text { direction of the sun where the wide side } \\
\text { is facing north and south } \\
\text { - Using vertical recycled wood as shad- } \\
\text { ing } \\
\text { - Use vegetation as shading on the bal- } \\
\text { cony } \\
\text { - Active shading device, for control and } \\
\text { response to sunlight } \\
\text { - Using natural light } \\
\text { Evaporative Cooling } \\
\text { - Using chilled ceiling panels to absorb } \\
\text { heat from equipment and building users } \\
\text { - Shower tower, utilizing air and water } \\
\text { as retail area coolers }\end{array}$ \\
\hline
\end{tabular}

Placement of the building elements that are applied as evaporative cooling is the side that has the hottest period. Combinations with shading elements can also be done. The direction of the wind facing the building also needs to be considered to create direct evaporation cooling to cool the building space's temperature.

\section{9 | Precedent}

In tropical climates, passive design is necessary to achieve efficient buildings. However, only a few buildings use evaporative cooling techniques in their application as energy efficiency optimization. Some precedents for implementing evaporative cooling can be seen in Table 3. Figure 18 shows the three buildings which applied passive design and evaporation cooling.

Mesiniaga Tower applies passive designs such as consideration of core placement, shading elements, skycourt, and vertical vegetation. The application of evaporative cooling in Mesiniaga Tower is located in the pool at the top of the building, reducing the temperature around the building (Figure 18). NBF Osaki uses a new exterior BIOSKIN based on the principles behind sudare, or traditional Japanese screens. BIOSKIN reduces the heat island effect by cooling the outside of the building with rainwater collected from the roof area by supplying special porous ceramic pipes. When water evaporates, it reduces the surface temperature of the ceramic and adjacent air. Based on experiments and simulations, it is estimated that around $2^{\circ} \mathrm{Celcius}$ can reduce the surrounding air temperature. In addition to the natural cooling effect, BIOSKIN sudare filters direct sunlight, reducing the $\mathrm{AC}$ load for a more significant reduction in $\mathrm{CO}_{2}$ emissions. 

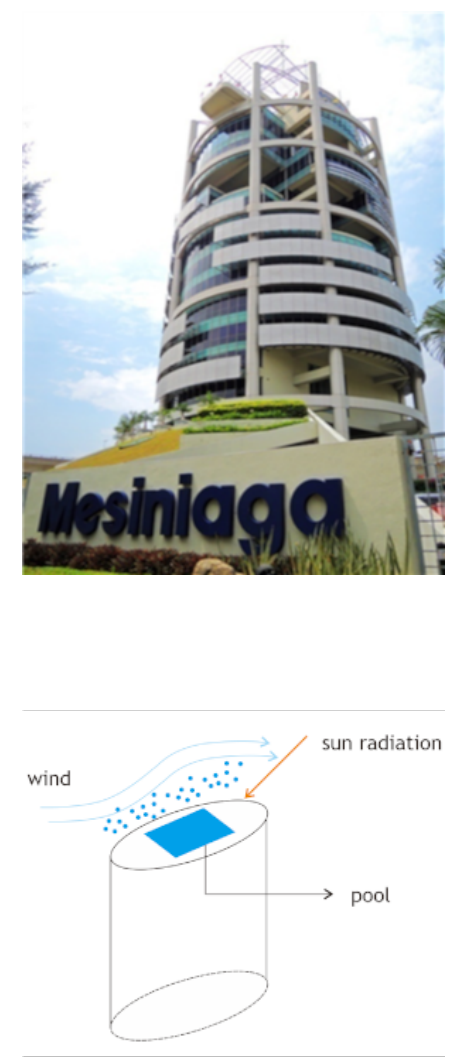

(a) Mesiniaga Tower
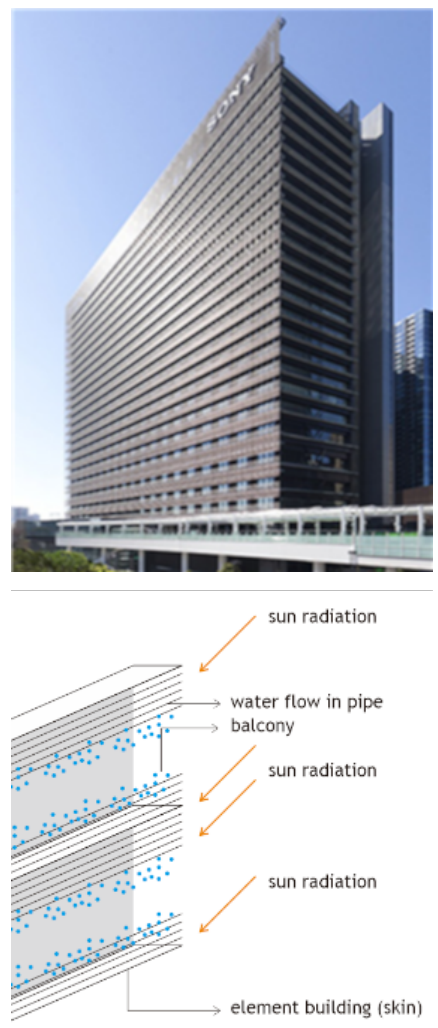

(b) NBF Osaki
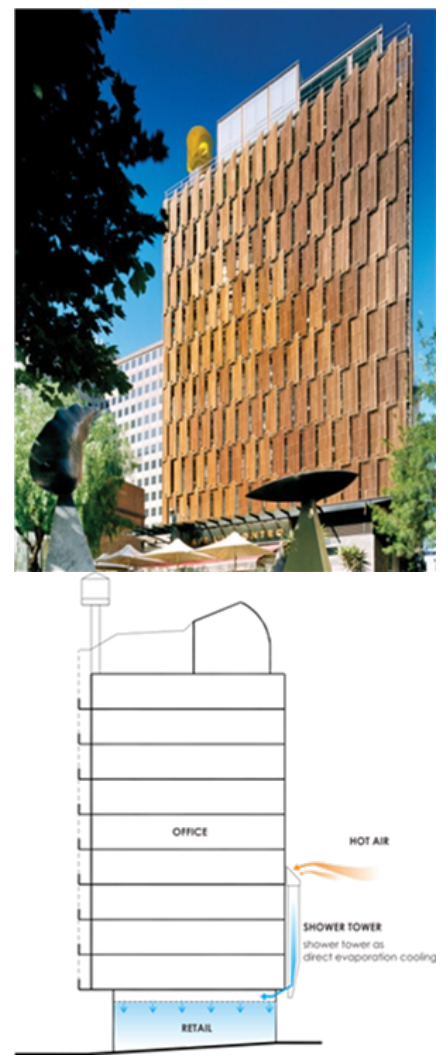

(c) Council House-2

FIGURE 18 Precedent with passive design and evaporative cooling.

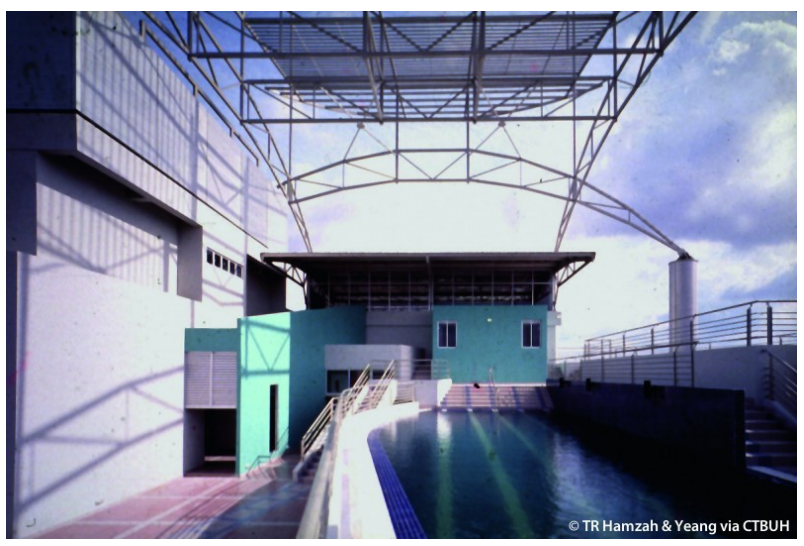

FIGURE 19 Evaporative cooling pool at Mesiniaga Tower.

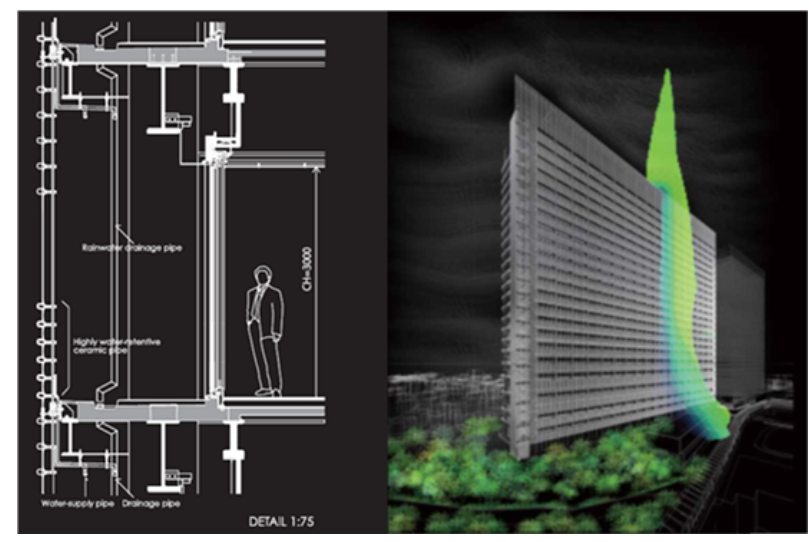

FIGURE 20 NBF Osaki implements indirect evaporation cooling.

Bioskin was placed on the east side. The Eastside is the heat of the morning sun. Overall, NBF Osaki implements an indirect evaporation cooling where cooling is carried out on the building's outside elements. The indirect evaporation cooling application is placed on the side that gets solar radiation for an extended period (Figure 19).

In the Council House 2 building, the principle of evaporative cooling is applied as cool air to the building's retail area. Hot air is captured and flowed through a shower tower. Hot air mixed with water will become cool air, an air source in the building. With a shower tower, the air temperature can be reduced by around $4^{\circ}$ Celcius. Evaporative cooling at Council House 2 is the application 


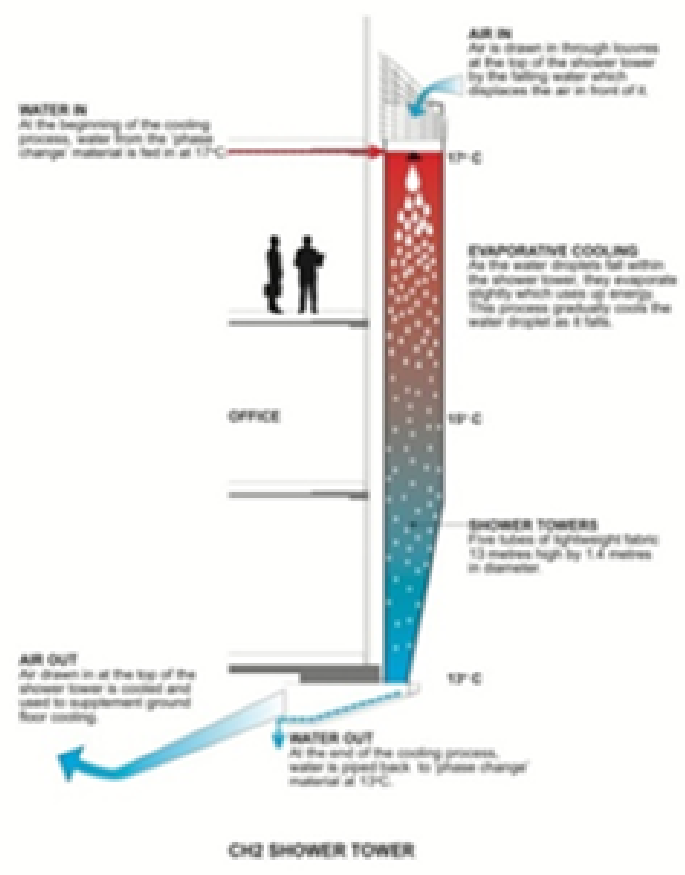

FIGURE 21 Council House 2 implements direct evaporation cooling.

of direct evaporative cooling, which changes the room's temperature to be cooler. Direct evaporation cooling is effective when more airflow brings cold air into the building room (Figure 20).

Based on precedents, the combination of passive design application aims to reduce the transfer of solar heat so that the increase in building heat can be minimized. Simultaneously, the application of evaporative cooling aims to make the temperature around the building and room temperature cooler by direct or indirect evaporation cooling.

\section{4 | CONCLUSION}

The design strategy of the energy-saving office building is considered in building heat control. The most significant building heat control that affects making heat gain is the building orientation, building core placement, shading elements, cross ventilation, and natural lighting. In addition, consideration of building shape has an impact on building heat gain. Aerodynamic shape and pattern provide more shading, improve natural ventilation, and decrease solar radiation.

In terms of evaporation cooling, a good application of evaporative cooling is to implement direct and indirect evaporation cooling. Direct evaporation cooling is more optimal with airflow (wind) support, while indirect evaporation cooling is applied to the side, which exposed solar radiation for an extended period.

\section{References}

1. Sayigh A. Sustainable High Rise Building in Urban Zones : Advantages, Challenges, and Global Case Studies. Cham, Switzerland: Springer International Publishing; 2017.

2. Norbert L, C W. Heating, Cooling, Lighting : Sustainable Design Methods for Architects. Hoboken, New Jersey: John Wiley \& Sons, Inc; 2015.

3. Elotefy H, Abdelmagid KSS, Morghany E, Ahmed TMF. Energy-Efficient Tall Buildings Design Strategies: A Holistic Approach. International Conference on Technologies and Materials for Renewable Energy, Environment and Sustainability, 
TMREES15 2015;74:1358-1369. http://dx.doi.org/10.1016/j.egypro.2015.07.782

4. Yeang K, Robert Powell. Designing the Ecoskyscraper: Premises for Tall Building Design. The Structural Design of Tall and Special Buildings 2007;16(4):411-427.

5. Yeang K. The Green Skyscraper: The Basis for Designing Sustainable Intensive Buildings.Munich. Munich,New York: Prestel; 1999.

6. Gonzalo R, Habermann KJ. Energy Efficient Architecture : Basics for Planning and Construction. Basel Boston: Birkhauser Architecture; 2006.

7. States OoA. Energy Efficiency Guidelines for Office Buildings in Tropical Climates. American States: Department of Sustainable Development; 2013.

8. Apritasari YD. Optimization Design of Light Shelf for Visual Comfort and Energy Savings in an Office Space. In: ECEEE 2017 Summer Study on Energy Efficiency Belambra Les Criques, Toulon/Hyères, France; 2017. p. 1237-1242.

9. Chungloo S, Limmeechokchai B. Application of Passive Cooling Systems in the Hot and Humid Climate: The Case Study of Solar Chimney and Wetted Roof in Thailand. Building and Environment 2007 sep;42(9):3341-3351.

10. Ripple J. Generative material simulation: Contemporary trends in parametric structural design. In: Structures and Architecture - Proceedings of the 3rd International Conference on Structures and Architecture, ICSA 2016 Guimarães, PORTUGAL: University of Minho; 2016. p. 283-289.

11. Abu Khadra A, Chalfoun N. Development of An Integrated Passive Cooling Facade Technology for Office Buildings in Hot Arid Regions. WIT Transactions on Ecology and the Environment 2014 jan;1:521-534.

12. Mainini AG, Speroni A, Zani A, Poli T. The Effect of Water Spray Systems on Thermal and Solar Performance of an ETFE Panel for Building Envelope. In: Procedia Engineering, vol. 155 Elsevier Ltd; 2016. p. 352-360.

13. Al Touma A, Ouahrani D. Performance Assessment of Evaporatively-Cooled Window Driven by Solar Chimney in hot and Humid Climates. Solar Energy 2018 jul;169:187-195.

How to cite this article: Savero R.R., Antaryama I.G.N., Soemardiono B. (2020), Review on Design Strategies of Energy Saving Office Building with Evaporative Cooling in Tropical Region, IPTEK The Journal of Technology and Science, 31(2):236-248. 